\title{
Antifungal Activity of Skin Coatings against Post Harvest Rots of Apple Cultivar Starking Delicious
}

\author{
Neelam Kumari ${ }^{1 *}$, J. N. Sharma² and Deepika Singh ${ }^{3}$ \\ ${ }^{1,2}$ Dept. of Plant Pathology, ${ }^{3}$ Dept. of Fruit Science, Dr. Y. S. Parmar University of Horticulture and Forestry, Nauni, \\ Solan, H.P. (173 230), India
}

\section{Corresponding Author}

Neelam Kumari

e-mail: neelkumari90@gmail.com

\author{
Article History \\ Article ID: IJEP0300 \\ Received in $05^{\text {th }}$ April, 2019 \\ Received in revised form $03^{\text {rd }}$ May, 2019 \\ Accepted in final form 20 ${ }^{\text {th }}$ May, 2019
}

\begin{abstract}
Essential oils and vegetable oils as skin coatings have the potential to replace the synthetic fungicides in the management of post harvest diseases of fruits and vegetables. This study was aimed to evaluate the antifungal efficacy of essential oils of eucalyptus, neem, clove, lemongrass, cinnamon and thyme; vegetable oils of linseed, castor, karanj, mustard and soyabean; anhydrous milk fat; paraffin wax and semperfresh against some important post harvest pathogens of apple fruits (Alternaria alternata, Trichothecium roseum, Monilinia fructigena, Aspergillus niger and Penicillium expansum). Neem oil (1\%) provided complete control of all the fungal decays under study. The next best treatments were eucalyptus oil, cinnamon oil and clove oil. Therefore, skin coatings of essential oils and vegetable oils after suitable formulation can be used for the control of post harvest diseases of fruits and vegetables instead of fungicidal treatments.
\end{abstract}

Keywords: Apple fruits, post harvest, skin coatings

\section{Introduction}

Himachal Pradesh has made tremendous strides in the production of high quality of apples during the last few decades and has revolutionized the socio-economic condition of hilly farmers in the state. It has become the number one commercial fruit crop of Himachal Pradesh, which is being grown over an area of $109.55^{\prime} 000$ hectare with total annual apple production of $625.20^{\prime} 000$ metric tonnes and productivity of the state is 5.74 metric tonnes per hectare (NHB, 2015).

Fungal infections are the main cause of post harvest rots of fruits and vegetables during storage, transport and cause significant economic losses in the commercialization phase (Gatto et al., 2011). Infections caused during post harvest conditions lowers the shelf life and adversely affect the market value of fruits (Tripathi et al., 2008). Moreover, mycotoxins the secondary metabolites produced by moulds have adverse effects on humans and animals (Zain, 2011). The contamination of fruits with mycotoxins has not only caused health hazards but also resulted in economic losses, especially for exporting countries.

Among the different fungal pathogens, Alternaria alternata, Botrytis cinerea, Glomerella cingulata, Monilinia fructigena and Penicillium expansum are the dominant ones causing post harvest losses in apple. Chemical fungicides provide the primary means for controlling post harvest fungal decay of fruits and vegetables. Continuous use of fungicides has faced two major obstacles; increasing public concern regarding contamination of fruits and vegetables with fungicidal residues, and proliferation of resistance in the pathogen populations. Food safety is one of the major issues related to fresh fruits and vegetables. The development of natural crop protective products as alternatives to synthetic fungicides is currently in the spotlight. The natural and bio-control fungicides might be a good alternative to the use of synthetic fungicides and in turn to fulfill consumer requirements for more natural and healthy foods. Application of essential oil is a very attractive method for controlling post harvest diseases. Essential oils and their components are gaining increasing interest because of their relatively safe status, their wide acceptance by consumers, and their exploitation for potential multi-purpose functional use (Ormancey et al., 2001; Tripathi et al., 2008).

\section{Materials and Methods}

\subsection{Fungal pathogens}

Isolates of Alternaria alternata, Monilinia fructigena, Trichothecium roseum, Aspergillus niger and Penicillium expansum were obtained from apple fruit samples (cv. Starking Delicious) expressing rot symptoms. Apple fruit samples were collected during survey made during 2015 and 2016 from different markets/stores/godowns of Shimla and Solan districts of Himachal Pradesh. The pathogens were isolated 
using standard phytopathological techniques. The diseased fruits were surface sterilized with absolute alcohol under aseptic conditions. Small bits of 1 to $2 \mathrm{~mm}$ size were taken from junction of diseased and healthy part of fruit with the help of sterilized sharp blade and scalpel. These bits were surface sterilized with sodium hypochlorite (1.0\%) for 10 to 20 seconds and washed thrice with sterilized distilled water under aseptic conditions. The bits were then placed on the sterilized filter paper to remove the excess moisture and subsequently transferred to sterilized Petri plates containing potato dextrose agar (PDA) medium. The inoculated Petri plates were incubated at $25 \pm 1^{\circ} \mathrm{C}$ in BOD incubator and examined daily for mycelial growth. The fungal growth developed in Petri plates was purified by hyphal tip technique and was further cultured on slants containing PDA. These slants of culture were preserved at $5{ }^{\circ} \mathrm{C}$ in the refrigerator for further studies. Stock cultures were maintained by regularly sub-culturing after 20 to 25 days.

The causal organisms were identified by studying their morphology and comparisons with standard authentic descriptions from literature (Marie-Jose et al., 2004; Al-Hindi, 2011; Jurick, 2014; Hamid et al., 2014; Vico et al., 2014).

\subsection{Skin coatings}

Essential oils of eucalyptus, neem, clove, lemongrass, cinnamon and thyme at 0.5 and $1.0 \%$ concentrations; vegetable oils of linseed, castor, karanj, mustard and soyabean at 2.0 and $4.0 \%$ concentrations; anhydrous milk fat and paraffin wax at 2.0 and $4.0 \%$ concentrations; semperfresh at 0.75 and $1.5 \%$ concentration were used as skin coating treatments. Oil suspensions were prepared by adding commercial oils to sterile distilled water containing $0.01 \%$ Tween 20 to obtain different concentrations. The emulsifier Tween 20 was added to enhance the solubility of oils.

\subsection{Evaluation of antifungal activity of skin coatings}

Starking Delicious apple fruits apparently free from physical damage and diseases were washed under tap water, air dried and then dipped in sterilized water containing essential oils of eucalyptus, neem, clove, lemongrass, cinnamon and thyme at 0.5 and $1.0 \%$ concentrations; vegetable oils of linseed, castor, karanj, mustard and soyabean at 2.0 and $4.0 \%$ concentrations; anhydrous milk fat and paraffin wax at 2.0 and $4.0 \%$ concentrations; semperfresh at 0.75 and $1.5 \%$ concentrations for $5 \mathrm{~min}$, then air dried. After $12 \mathrm{~h}$ of treatment, inoculation of treated fruits with different test fungi was carried out by Lancet method of Kaul and Lall (1974). Each treatment was replicated thrice with five fruits per replicate for a particular test fungus. Inoculated untreated fruits were kept as control for comparison. All treated and untreated fruits were placed at temperature and humidity control chamber and observed for fruit rotting. Per cent fruit rot was recorded by the formula given by Srivastava and Tondon (1968) when the control fruits rotted completely:

Per cent fruit rot $=(\mathrm{W}-\mathrm{w}) / \mathrm{W} \times 100$
Where,

$W=$ weight of the fruits before inoculation

$\mathrm{w}=$ weight of the fruits after removal of the rotten tissue

\section{Results and Discussion}

Perusal of data presented in Table 1 revealed that skin coating with $1 \%$ neem oil provided complete control of all the fungal decays under study. Similar observations were recorded by Wijewardane and Guleria (2009). Steinhauer (1987) isolated a compound with antifungal activity from neem kernal extracts which has been used for the control of phytopathogenic fungi such as Penicillium expansum. The next effective skin coatings were eucalyptus oil, cinnamon oil and clove oil at $1 \%$ concentration with per cent control of $99.21,98.70$ and $97.93 \%$, respectively. Accordingly, it was observed that apples coated with lemongrass oil, thyme oil and pungent mustard oil withstood the onslaught of fungal pathogens to the maximum with per cent control of $97.80,96.77$ and $90.89 \%$ respectively, followed by linseed, castor and karanj oils which were rated at par among themselves in their effectiveness. However, semperfresh and paraffin wax were the least effective at all the test concentrations with per cent control of 38.63, 44.18 and $48.09,61.12 \%$, respectively. Earlier, apples coated with mustard oil, paraffin and castor oil were reported to check the infection of a large number of pathogens (Sumbali and Mehrotra, 1980; Kaul and Munjal, 1982; Sharma and Kaul, 1988). Application of hydrogenated groundnut oil provided effective control of Alternaria rot of apples (Tak et al., 1985). Skin coating with neem oil had also completely checked blue mould rot in apples (Kerni et al., 1983).

The extent of rotting by the test fungi was variable amongst themselves in variously coated apples. Minimum spoilage in such apples was due to $T$. roseum (13.61\%) and maximum by $P$. expansum (27.57\%) followed by A. niger (23.74\%), A. alternata $(19.48 \%)$ and $M$. fructigena (14.65\%) in descending order.

The interaction between treatments and test fungi revealed that $M$. fructigena was completely checked on apples coated with essential oils of eucalyptus, neem, clove, lemongrass, cinnamon and thyme at both concentrations and similar was the case with $T$. roseum which was somewhat more tolerant to lower concentration of clove oil. Mustard oil provided $100 \%$ inhibition of $T$. roseum at both the concentrations and of $M$. fructigena at $4 \%$ concentration. However, for A. niger, fruit coating with eucalyptus, neem, cinnamon, lemongrass and clove oil were effective but other treatments were less effective. Neem oil provided $100 \%$ inhibition of $P$. expansum at both the concentrations and of $A$. alternata at $1 \%$ concentration. The next best coatings against both the pathogens were cinnamon and eucalyptus oil. A. alternata was completely inhibited by fruit coating with thyme oil. Semperfresh, paraffin wax and anhydrous milk fat were least effective in controlling all the fungal decays under study. One of the treatments for extending the post harvest life of apple, 


\begin{tabular}{|c|c|c|c|c|c|c|c|c|}
\hline \multirow[t]{2}{*}{ Treatment } & \multirow{2}{*}{$\begin{array}{c}\text { Conc. } \\
(\%)\end{array}$} & \multicolumn{5}{|c|}{$\%$ fruit rot } & \multirow[t]{2}{*}{ Mean } & \multirow[t]{2}{*}{$\%$ contro } \\
\hline & & A. alternata & T.roseum & M. fructigena & A. niger & P. expansum & & \\
\hline \multirow[t]{2}{*}{ Eucalyptus oil } & 0.5 & 5.02 & 0.00 & 0.00 & 0.00 & 9.30 & $2.86(9.73)$ & 97.14 \\
\hline & 1.0 & 0.00 & 0.00 & 0.00 & 0.00 & 3.95 & $0.79(5.10)$ & 99.21 \\
\hline \multirow[t]{2}{*}{ Neem oil } & 0.5 & 4.28 & 0.00 & 0.00 & 3.69 & 0.00 & $1.59(7.24)$ & 98.41 \\
\hline & 1.0 & 0.00 & 0.00 & 0.00 & 0.00 & 0.00 & $0.00(0.00)$ & 100.00 \\
\hline \multirow[t]{2}{*}{ Clove oil } & 0.5 & 6.49 & 4.65 & 0.00 & 8.65 & 10.64 & 6.09 (14.28) & 93.91 \\
\hline & 1.0 & 0.00 & 0.00 & 0.00 & 4.11 & 6.23 & $2.07(8.27)$ & 97.93 \\
\hline \multirow[t]{2}{*}{ Lemongrass oil } & 0.5 & 0.00 & 0.00 & 0.00 & 7.89 & 13.38 & 4.26 (11.91) & 95.74 \\
\hline & 1.0 & 0.00 & 0.00 & 0.00 & 4.42 & 6.60 & $2.20(8.53)$ & 97.80 \\
\hline \multirow[t]{2}{*}{ Cinnamon oil } & 0.5 & 4.79 & 0.00 & 0.00 & 3.96 & 5.08 & $2.77(9.58)$ & 97.23 \\
\hline & 1.0 & 2.44 & 0.00 & 0.00 & 1.45 & 2.64 & $1.30(6.54)$ & 98.70 \\
\hline \multirow[t]{2}{*}{ Thyme oil } & 0.5 & 0.00 & 0.00 & 0.00 & 11.52 & 15.70 & 5.45 (13.49) & 94.55 \\
\hline & 1.0 & 0.00 & 0.00 & 0.00 & 6.09 & 10.04 & $3.23(10.35)$ & 96.77 \\
\hline \multirow[t]{2}{*}{ Linseed oil } & 2.0 & 20.95 & 15.13 & 16.21 & 24.12 & 29.67 & $21.22(27.42)$ & 78.78 \\
\hline & 4.0 & 15.22 & 13.98 & 14.65 & 21.07 & 25.53 & $18.09(25.16)$ & 81.91 \\
\hline \multirow[t]{2}{*}{ Castor oil } & 2.0 & 20.91 & 14.91 & 15.90 & 23.99 & 28.62 & $20.86(27.17)$ & 79.14 \\
\hline & 4.0 & 14.62 & 13.90 & 14.22 & 20.95 & 25.72 & $17.88(25.00)$ & 82.12 \\
\hline \multirow[t]{2}{*}{ Karanj oil } & 2.0 & 17.68 & 14.53 & 14.80 & 22.65 & 26.68 & $19.27(26.03)$ & 80.73 \\
\hline & 4.0 & 14.74 & 12.01 & 12.61 & 20.18 & 23.60 & $16.63(24.06)$ & 83.37 \\
\hline \multirow[t]{2}{*}{ Mustard oil } & 2.0 & 11.69 & 0.00 & 15.63 & 22.70 & 23.80 & $14.76(22.58)$ & 85.24 \\
\hline & 4.0 & 9.55 & 0.00 & 0.00 & 15.85 & 20.14 & $9.11(17.56)$ & 90.89 \\
\hline \multirow[t]{2}{*}{ Soyabean oil } & 2.0 & 23.86 & 15.60 & 17.72 & 30.66 & 35.11 & $24.59(29.72)$ & 75.41 \\
\hline & 4.0 & 16.40 & 14.03 & 16.99 & 25.77 & 29.57 & $20.55(26.95)$ & 79.45 \\
\hline \multirow[t]{2}{*}{ Anhydrous milk fat } & 2.0 & 29.65 & 18.67 & 20.64 & 33.64 & 37.96 & $28.11(32.01)$ & 71.89 \\
\hline & 4.0 & 20.58 & 15.65 & 17.17 & 28.02 & 32.71 & $22.83(28.53)$ & 77.17 \\
\hline \multirow[t]{2}{*}{ Paraffin wax } & 2.0 & 54.98 & 34.49 & 36.92 & 59.34 & 73.84 & $51.91(46.08)$ & 48.09 \\
\hline & 4.0 & 41.94 & 30.11 & 31.28 & 45.00 & 46.05 & $38.88(38.56)$ & 61.12 \\
\hline \multirow[t]{2}{*}{ Semperfresh } & 0.75 & 67.67 & 40.59 & 43.56 & 73.95 & 81.06 & $61.37(51.55)$ & 38.63 \\
\hline & 1.5 & 61.33 & 36.39 & 36.58 & 68.87 & 75.95 & $55.82(48.32)$ & 44.18 \\
\hline Control & - & 100.00 & 100.00 & 100.00 & 100.00 & 100.00 & $\begin{array}{l}100.00 \\
(89.96)\end{array}$ & - \\
\hline Mean & - & 19.48 & 13.61 & 14.65 & 23.74 & 27.57 & - & - \\
\hline
\end{tabular}

CD (0.05) Treatment: 0.316; Concentration: 0.119; Treatment×Concentration: 0.446; Test pathogen: 0.189; Treatment $\times$ Test pathogen: 0.706; Concentration $\times$ Test pathogen: 0.267; Treatment $\times$ Concentration $\times$ Test pathogen: 0.998; *Figures in parentheses are arc sine transformed values

pear and plum has been reported by coating the skin with a product called 'Prolong', a mixture of sucrose esters of fatty acids and polysaccharide (Banks and Harper, 1981). It is known to alter the permeability of fruits to gases in such a way that oxygen exchange is reduced considerably, while carbon dioxide is little affected.
Lemongrass and citral essential oils at $6 \mathrm{ml} \mathrm{l}^{-1}$ as well as chitosan + citral or lemongrass essential oil mixtures at $3 \mathrm{gl}^{-1}+3$ $\mathrm{mll}^{-1}$ or $4 \mathrm{~g} \mathrm{l}^{-1}+4 \mathrm{ml} \mathrm{l}^{-1}$ caused complete growth reduction of $P$. digitatum and $P$. italicaum (El-Mohamedy and Ziedan, 2015). The inhibitory effect of citral on post harvest pathogens was also reported by Abd-El-Kareem and Abd-Alla (2002), Chein 
et al. (2007); Faten (2010).

\section{Conclusion}

The results revealed that $1 \%$ concentration of neem oil, eucalyptus oil, clove oil, cinnamon oil, lemongrass oil, thyme oil and mustard oil as skin coatings were most effective against all the fungal decays under study. Thus, these skin coatings are an effective alternative for the control of post harvest decays of fruits and vegetables over the synthetic fungicides. However, potential use of essential oils and vegetable oils requires a detailed examination of these botanicals, their mode of action, their dispersion in fruit tissues and development of suitable formulations for commercial use.

\section{References}

Abd-El-Kareem, F., Abd-Alla, M.A., 2002. Citral for controlling post harvest diseases of navel orange fruits. Egyptian Journal of Applied Science 17, 238-256.

Al-Hindi, R.R., Al-Nazada, A.R., Mohamed, S.A., 2011. Isolation and identification of some fruit spoilage fungi: Screening of plant cell wall degrading enzymes. African Journal of Microbiology Research 5, 443-448.

Banks, N.H., Harper, G.R., 1981. Gaseous exchange, fruit surface and coating. In: Proceeding of $150^{\text {th }}$ Anniversary of British Association for the Advancement of Science, Annual meeting, 3 August to 4 September 1981. Sec. D. No. 81.

Chein, P.J., Sheu, F., Lin, H.R., 2007. Coating citrus (Murcott tangor) fruit with low molecular weight chitosan increases postharvest quality and shelf life. Food Chemistry 100, 1160-1164.

El-Mohamedy, R.S., Riad, El-Sayed, H. Ziedan, 2015. First record of core rot disease on apple fruit cv. Anna 106 local cultivar in Egypt. Journal of Agricultural Technology 11, 1371-1380.

Faten, M.A., 2010. Combination between citral and chitosan for controlling sour rot disease of lime Fruits. Research Journal of Agriculture and Biological Sciences 6, 744-749.

Gatto, M.A., Ippolito, A., Linsalata, V., Cascarano, N.A., Nigro, F., Vanadia, S., Di Venere, D., 2011. Activity of extracts from wild edible herbs against postharvest fungal diseases of fruit and vegetables. Postharvest Biology and Technology 61, 72-82.

Hamid, M.I., Hussain, M., Ghazanfar, M.U., Raza, M., Liu, X.Z., 2014. Trichothecium roseum causes fruit rot of tomato, orange and apple in Pakistan. Plant Disease 98, 1271.

Jurick, W.M., 2014. First report of Alternaria alternata causing post harvest decay on apple fruit during cold storage in Pennsylvania. Plant Disease 98, 690.

Kaul, J.L., Lall, B.S., 1974. A new method for inoculating citrus fruits. Science and Culture 40, 375-376.
Kaul, J.L., Munjal, R.L., 1982. Apple losses in Himachal Pradesh due to post harvest fungal pathogens. Indian Journal of Mycology and Plant Pathology 18, 137-139.

Kerni, P.N., Shant, P.S., Singh, D., 1983. Effect of various vegetable oils in controlling blue mould (Penicillium expansum) rot of apples. Progressive Horticulture 15, 129-131.

Marie-Jose, Cote, Marie-Claude, Tardif, Allison, J.M., 2004. Identification of Monilinia fructigena, M. fructicola, $M$. laxa and Monilia polystroma on inoculated and naturally infected fruit using multiplex PCR. Plant Disease 88, 1219-1225.

NHB, 2015. Horticultural Statistics at a Glance. National Horticulture Board, Gurgaon. nhb.gov.in.

Ormancey, X., Sisalli, S, Coutiere, P., 2001. Formulation of essential oils in functional perfumery. Parfums, Cosmetiques, Actualites 157, 30-40.

Sharma, R.L., Kaul, J.L., 1988. Efficacy of fruit wrappers and skin coatings against brown rot (Monilinia spp.) in stored apples. Plant Disease Research 3, 247-250.

Srivastava, M.P., Tandon, R.N., 1968. Influence of temperature on Botryodiplodia rot of citrus and sapodilla. Indian Phytopathology 21, 195-197.

Steinhauer, B., 1987. Antifungal compounds from Azadirachta indica. In: Kleeberg $\mathrm{H}$ (ed) Practice oriented results on use and production of neem ingredients and pheromones. Druck and Graphic, Giessen, 93-97.

Sumbali, G., Mehrotra, R.S., 1980. Evaluation of some fixed oils for the control of certain temperate fruit rot fungi. Indian Phytopathology 33, 517.

Tak, S.K., Verma, O.P., Gupta, A.K., Pathak, V.N., 1985. Control of Alternaria rot of apple fruits by post harvest application of chemicals. Indian Phytopathology 38, 471-474.

Tripathi, P., Dubey, N.K., Shukla, A.K., 2008. Use of some essential oils as post-harvest botanical fungicides in the management of grey mould of grapes caused by Botrytis cinerea. World Journal of Microbiology and Biotechnology 24, 39-46.

Vico, I., Duduk, N., Vasic, M., Nikolic, M., 2014. Identification of Penicillium expansum causing postharvest blue mould decay of apple fruit. Pesticides and Phytomedicine 29, 257-266.

Wijewardane, R.M.N.A., Guleria, S.P.S., 2009. Combined effects of pre-cooling, application of natural extracts and packaging on the storage quality of apple (Malus domestica) cv. Royal Delicious. Tropical Agricultural Research 21, 10-20.

Zain, M.E., 2011. Impact of mycotoxins on humans and animals. Journal of Saudi Chemical Society 15, 129-144. 